\title{
ARGUMEN TENTANG TANTANGAN TERHADAP PANCASILA DALAM KEHIDUPAN BERBANGSA DAN BERNEGARA
}

\author{
GILANG \\ gilangscoopy110@gmail.com \\ 20220051 \\ STIE AKBP KBP PADANG
}

\section{A. PENDAHULUAN}

\section{Latar Belakang Permasalahan Terhadap Pancasila}

Sejarah mengatakan bahwa pancasila disusun dan terbentuk berdasarkan pemikiran serta keilmuan yang dimiliki para bapak bangsa, dari berbagai pemikiran banyak kepala yang dituangkan dalam sebuah pedoman dasar dan pokok aturan bangsa serta memiliki tujuan yang sama dengan demikian terlahirnya sebuah ideology bangsa Indonesia yang disebut dengan pancasila.

Pancasila merupakan pedoman dasar bangsa Indonesia yang didalamnya telah tertuang nilainilai lughur serta akan terus berkembang relevansinya seiring dengan perkembangan zaman dan juga sifat pancasila yang tidak kontekstual atau bisa dibilang berlakunya tidak berdasarkan waktu. Desain khusus dari para pemikir bangsa menunjukkan bahwa pancasila akan terus berlaku.

Permasalahan tersebut yang kemudian menjadi suatu tantangan dimana tantangan tersebut muncul untuk menguji kekokohan pondasi pancasila serta kekuatan yang terkandung dalam pancasila yang menjadi jati diri bangsa.

Dalam era modernisasi sekarang ini pancasila dihadapkan dengan berbagai tantangan baik dari dalam maupun luar. Adapun tantangan dari dalam diantaranya berupa berbagai gerakan separatis yang hendak memisahkan diri dari Negara kesatuan republic Indonesia yang 
mengakibatkan munculnya disintegrasi serta mentalis bangsa. Penangganan yang tidak tepat dan tegas dalam menghadapi gerakan-gerakan tersebut akan menjadi ancaman serius bagi tetap eksisnya pancasila diindonesia.

Tantangan yang muncul dari luar yaitu arus globalisasi yang masuk dan menggerus budaya dan kepribadian masyarakat serta sedikit banyak sudah mulai berpindah haluan dan bahkan merangkak bergeser dari budaya asli masyarakat menjadi budaya asing yang tidak sesuai dengan jati diri pancasila serta kepribadian bangsa. Jadi untuk menyelesaikan segala permasalahan yang ada seyokyanya dalam penyelesaiaan tersebut harus mengacu kepada pedoman dasar yaitu pancasila, karena pancasila merupakan ideology yang menjadi pokok dasar aturan bangsa yang didesain secara khusus.

Dengan desain yang secara khusus jadi segala permasalahan dan tantangan yang muncul akan diselesaikan berdasarkan ideology pancasila.

2.Rumusan Masalah

a. Bagaimana tantangan pancasila sebagai ideology diera globalisasi

b. Bagaimana tantangan pancasila sebagai ideology diera reformasi

c. Apa penyebab lunturnya ideology pancasila

d. Apa penyebab hambatan pengamalan nilai-nilai pancasila

3. Tujuan

a. Mengetahui tantangan pancasila sebagai ideology diera globalisasi

b. Mengetahui tantangan pancasila sebagai ideology diera reformasi

c. Mengetahui penyebab lunturnya ideology pancasila

d. Mengetahui penyebab hambatan pengamalan nilai-nilai pancasila 


\section{B. PEMBAHASAN}

\section{A. Tantangan Pancasila Sebagai Ideologi Diera Globalisasi}

Sekarang ini abad ke 21, kita hidup di zaman yang global atau globalisasi. Proses globalisasi yang menimbulkan tantangan dan ancaman bagi bangsa Indonesia dewasa ini adalah desakan konsumetisme yang melanda kehidupan bangsa bagaikamn tsunami. Globalisasi membawa masyarakat dapat menyaksikan gedung-gedung menjualang dan hotel-hotel mewah. Globalisasi mendorong mereka untuk mengunjungi mal-mal yang penuh dengan barang-barang produk impor. Demikian juga dengan iklan-iklan televise yang dibanjiri dengan produk-produk sehingga membawa pada sikap konsumerisme.

Saat ini bangsa Indonesia dibuat sebagai "bangsa importir" yang terpaksa hidup dari barangbarang kebutuhan yang berasal dari luar negri. Dengan demikian masyarakat menjalani kehidupan yang palsu, karena masyarakat dibuat mewah walaupun sebenarnya miskin, karena produk yang dikonsumsi buatan Negara lain.

Ancaman konsumerisme terletak dalam kenyataan bahwa kekuatan-kekuatan perusahaan ekonomi merupakan pemegang kekuatan global yang mampu menjadikan konsumerisme sebagai alat untuk mendatangkan keuntungan dengan mengeksploitasi kondisi bangsa-bangsa miskin yang bergantung kepada kekuatan-kekuatan ekonomi global tersebut. Dengan kata lain, konsumerisme menjadi alat untuk mempertahankan dominasi kekuatan ekonomi global terhadap bangsa-bangsa yang menderita.

Oleh karena itu, agar masyarakat dapat hidup bebas sesuai dengan jati dirinya sepatutnya bangsa Indonesia bangkit dari keterpurukan. Yakni dengan menggalang kekuatan untuk mencegah konsumerisme dan ketergantungan tersebut dengan membuat bangsa berorientasi kepada kerja yang produktif. Ini berarti menumbuhkan etos kerja yang menjadi andalan masyarakat produktif. 
Melalui proses itu bangsa Indonesia akan menghargai hasil karyanya sendiri dan mempunyai kepercayaan diri karena etos kerja adalah wujud yang mencerminkan perkembangan dan peningkatan harkat bangsa sebagai manusia.

Dengan meninggalkan bentuk kehidupan yang palsu dan semua itu, bangsa Indonesia akan kembali sebagai bangsa yang sadar akan harkatnya sendiri untuk mampu bersaing.

\section{Tantangan Dari Dalam}

Tantangan berat yang harus dihadapi ke dalam adalah masalah mentalitas bangsa. Sikap-sikap yang melemahkan bangsa Indonesia seperti oportunis dan pragmatis yang melemahkan ketahanan bangsa dan merenggangkan solidaritas terhadap seksama. Sikap-sikap itu membuka lebar-lebar merajalelanya nafsu serakah di segala bidang, keserakahan untuk menguasai harta benda, untuk berkuasa dan untuk dihormati.

Kondisi itu mendorong orang untuk berlaku tidak jujur, tidak adil, dan bahkan bertindak semenamena dengan menyalahgunakan wewenang, menjalankan $\mathrm{KKN}$, dan tidak segan melakukan tindakan kekerasan dan kriminalitas. Disposisi mental seperti itu membuat seseorang mudah berbohong, munafik, sanggup berkhianat terhadap sahabatnya, hingga tega menjual bangsa dan tanah airnya. Kondisi demikian memberi peluang yang makin besar bagi dominasi kelompok kepentingan global.

Oleh karena itu untuk mengatasi keterpurukan bangsa dan membangun bangsa yang seutuhnya, kita perlu meningkatkan ketahanan budaya dan ketahanan pangan bangsa dan mengintegrasikannya melalui tindakan-tindakan komunikatif ke semua instituasi. Sehingga

dengan ketahanan pangan, maka bangsa ini mampu memenuhi kebutuhannya sendiri. Sedangkan 
ketahanan budaya akan menjadi benteng bagi derasnya budaya global yang tidak sesuai dengan budaya bangsa.

\section{B. Penyebab Lunturnya Ideologi Pancasila}

Penyebab lunturnya ideology pancasila yang merupakan tantangan berat dalam mengukuhkan ideology pancasila adalah sebagai berikut :

1.Melemahnya Penghayatan Terhadap Pancasila Sebagai Pandangan Hidup Bangsa.

Pancasila merupakan gagasan bangsa Indonesia yang merupakan kesatuan yang bulat dan utuh. Oleh sebab itu pancasila disebut juga kepribadian bangsa Indonesia. Setiap Negara yang ingin memantapkan jati dirinya pertama-tama harus mengetahui dan merumuskan dengan jelas arah dan tujuan yang ingin dicapai. Untuk itu diperlukan pandangan hidup.

Pancasila dijadikan pandangan hidup berbangsa dan bernegara sejak proklamasi kemerdekaan tahun penetapan pandangan hidup yang berdasarkan pancasila ini dilakukan berdasarkan kesepakatan dan kesadaran penuh bangsa Indonesia. Dengan pancasila, bangsa Indonesia telah mampu memecahkan berbagai permasalahan di bidang politik, ekonomi dan budaya yang timbul dalam perubahan sosial budaya yang bersifat global.

2.Pengaruh Unsur Budaya Dalam Pemakaiaan Bahasa Indonesia.

Bangsa Indonesia perlu mensyukuri dan sekaligus bangga karena memiliki bahasa nasional yang diakui, dipelajari dan dijadikan sebagai jati diri bangsa, khususnya dalam berkomunikasi. Modernisasi dan globalisasi juga ikut mempengaruhi atau mungkin mengubah berbagai unsur bahasa yang kita miliki, misalnya perbendaharaan kata, gaya berbahasa dan strutur pembahasan

yang digunakan. Ini semua menjadi tantangan agar kita dapat membangun bahasa Indonesia 
tanpa menghilangkan ciri khas bahasa itu sendiri, yang terbukti dapat mempersatukan berbagai suku, etnis dan agama di seluruh Indonesia.

\section{Berkurangnya Legitimasi Agama.}

Banyak sarjana Sosiologi dan Antropologi beranggapan bahwa ketika agama berhadapan dengan modernisasi, peranannya sebagai factor legitimasi utama dalam masyarakat akan tersisihkan dan digantikan oleh lembaga-lembaga kemasyarakatan yang dibentuk oleh masyarakat itu sendiri atas dasar kemajuan ilmu pengetahuan.

Gencarnya modernisasi dan globalisasi, sedikit banyak telah mempengaruhi pola beragama dan terhadap kepercayaan dalam masyarakat Indonesia. Menghadapi kenyataan ini, agama dituntut dapat senantiasa menjawab tantangan global tersebut. Caranya dengan menggali nilai-nilai dan melakukan redifinisi terhadap konsep-konsep beragama yang tidak relevan lagi dengan tuntutan zaman. Namun bukan berarti kita mengubah ajaran mendasar dari agama dan keyakinan yang kita anut selama ini.

\section{Dekadensi Moral dan Kekacauan Kemanusiaan.}

Dekadensi moral adalah melemahnya atau terkikisnya nilai-nilai kemanusiaan, kasih sayang dan kebersamaan didalam diri manusia. Semua ini melahirkan manusia-manusia yang suka merampas hak orang lain dan tidak mempedulikan nasib sesamanya.

5.Perubahan Pola Perilaku Dalam Pergaulan.

Pola perilaku yang hingga saat ini masih ditemukan dan merupakan warisan leluhur diantaranya adalah kekeluargaan, musyawarah untuk mencapai mufakat dan gotong royong. Semua ini menjadi ciri khas bangsa Indonesia yang tidak dimiliki oleh bangsa-bangsa lain. Akan tetapi dengan semakin derasnya arus globalisasi mau tidak mau kepribadian tersebut akan terpengaruh 
atau mungkin bisa dikatakan tercemar oleh corak kebudayaan asing yang lebih mementingkan individualisme, formalisme, kontrak kerja resmi dan lain sebagainya.

Dalam menghadapi tantangan global, Selo Soemardjan menyatakan bahwa bangsa Indonesia membutuhkan unsur-unsur kepribadian sebagai berikut :

$\checkmark$ Kemampuan dan kebiasaan berpikir secara rasional dan realistis serta objektif dalam menghadapi masalah-masalah yang dijumpai. Kemampuan ini menjadi sarana untuk bekerja secara sistematis, efisien dan efektif.

$\checkmark$ Kesadaran akan hak dan kewajiban sebagai warga masyarakat dan warga Negara untuk berperilaku yang tidak melanggar nilai-nilai sosial dan kaidah-kaidah hukum.

$\checkmark$ Memiliki rasa harga diri dan kepercayaan pada diri sendiri untuk ikut serta dalam tata masyarakat yang diwarnai dengan system bersaing.

$\checkmark$ Memiliki pengetahuan yang luas dan suatu keahlian yang ditekuni secara professional.

$\checkmark$ Mempunyai cita-cita hidup yang ingin dicapai melalui segala jalan yang sah dan etis yang dapat dibenarkan.

\section{Hambatan Pengamalan Nilai-Nilai Pancasila}

Dalam implementasi nilai-nilai pancasila tidak selalu berjalan mulus. Banyak sekali hambatan-hambatan yang terjadi. Disebutkan bahwa hambatan itu terjadi karena proses globalisasi yang begitu cepat setelah perang dunia ke II, membawa masyarakat Indonesia cenderung berorientasi pada nilai yang dating dari luar. Nilat individual, materialistis, pragmatis 
semakin kuat, lebih-lebih dengan perkembangan pariwisata yang pesat dan gelombang hegemoni pasar bebas.

Adapun hambatan-hambatannya antara lain sebagai berikut :

$\checkmark$ Pada sila pertama (Ketuhanan Yang Maha Esa) : masih terasa ada gangguan dengan munculnya terorisme, perusakan tempat ibadah, paham-paham aliran sesat, dll yang jelasjelas bertentangan dengan nilai yang tersirat dalam sila pertama yaitu toleransi antar umat beragama.

$\checkmark$ Pada sila kedua (Kemanusiaan Yang Adil dan Beradab) : di Indonesia masih terdapat perbuatan yang tidak manusiawi seperti penganiayaan terhadap anak sendiri, majikan kepada pembantunya dll. Hal itu bertentangan dengan prinsip kemanusiaan yang mengedepankan kasih sayang sesama manusia dan rasa saling menghormati antar manusia.

$\checkmark$ Pada sila ketiga (Persatuan Indonesia) : banyak sekali daerah-daerah yang ingin melepaskan diri dari NKRI, juga perang antar suku, antar daerah, antar desa yang hanya karena masalah sepele.

$\checkmark$ Pada sila keempat (Kerakyatan Yang Dipimpin Oleh Hikmat Kebijaksanaan Dalam Permusyawaratan Perwakilan) : dalam mengambil keputusan, kalangan atas masih mengutamakan kepentingan sendiri tanpa memikirkan nasib rakyat kecil. Hal ini sangat bertolak belakang dengan tujuan dewan perwakilan sebagai wakil rakyat yang mengutamakan kepentingan rakyat.

$\checkmark$ Pada sila kelima (Keadilan Sosial Bagi Seluruh Rakyat Indonesia) : tampak sekali ketidakadilan yang terjadi di Indonesia. Seperti kasus penyuapan terhadap hakim. 


\section{PENUTUP}

Permasalahan permasalahan yang terjadi di Indonesia saat ini menunjukan bahwa usaha membangun kebersamaan dalam kesatuan dan persatuan bangsa Indonesia berdasarkan ideology pancasila selama ini belum berhasil sepenuhnya. Hal ini tentu saja mengancam kesatuan Negara Republik Indonesia. Dimana letak nilai dasar pancasila sebagai persatuan Indonesia. Diperlukan tindakan yang nyata dari kita sebagai bangsa Indonesia dalam bagaimana melaksanakan nilainilai yang terkandung dalam ideologi dan lalu yang kedua bagaimana nilai-nilai tersebut dapat dilaksanakan oleh pribadi masing-masing dalam kehidupan sehari hari secara pribadi, anggota masyarakat dan Negara. Jika kita semua tahu benar dan mengerti bahkan menerapkan asas dari ideologi pancasila dalam kehidupan kita sehari hari, maka permasalahan permasalahan ini tidak akan terjadi.

\section{DAFTAR PUSTAKA}

Darmini Roza dan Laurensius Arliman S Peran Pemerintah Daerah Di Dalam Melindungi Hak Anak Di Indonesia, Masalah-Masalah Hukum, Volume 47, Nomor 1, 2018.

Laurensius Arliman S, Komnas HAM dan Perlindungan Anak Pelaku Tindak Pidana, Deepublish, Yogyakarta, 2015.

Laurensius Arliman S, Penguatan Perlindungan Anak Dari Tindakan Human Trafficking Di Daerah Perbatasan Indonesia, Jurnal Selat, Volume 4, Nomor 1, 2016.

Laurensius Arliman S, Problematika Dan Solusi Pemenuhan Perlindungan Hak Anak Sebagai Tersangka Tindak Pidana Di Satlantas Polresta Pariaman, Justicia Islamica, Volume 13, Nomor 2, 2016.

Laurensius Arliman S, Pelaksanaan Perlindungan Anak Yang Tereksploitasi Secara Ekonomi Oleh Pemerintah Kota Padang, Veritas et Justitia, Volume 2, Nomor 1, 2016. 
Laurensius Arliman S, Kedudukan Ketetapan MPR Dalam Hierarki Peraturan PerundangUndangan Di Indonesia, Lex Jurnalica, Volume 13, Nomor 3, 2016.

Laurensius Arliman S, Komnas Perempuan Sebagai State Auxialiary Bodies Dalam Penegakan Ham Perempuan Indonesia, Justicia Islamica, Volume 14, Nomor 2, 2017.

Laurensius Arliman S, Peranan Pers Untuk Mewujudkan Perlindungan Anak Berkelanjutan Di Indonesia, Jurnal Ilmu Hukum Tambun Bungai, Volume 2, Nomor 2, 2017.

Laurensius Arliman S, Mewujudkan Penegakan Hukum Yang Baik Untuk Mewujudkan Indonesia Sebagai Negara Hukum, Jurnal Hukum Doctrinal, Volume 2, Nomor 2, 2017.

Laurensius Arliman S, Participation Non-Governmental Organization In Protecting Child Rights In The Area Of Social Conflict, The 1st Ushuluddin and Islamic Thought International Conference (Usicon), Volume 1, 2017.

Laurensius Arliman S, Partisipasi Masyarakat Dalam Pembentukan Perundang-Undangan Untuk Mewujudkan Negara Kesejahteraan Indonesia, Jurnal Politik Pemerintahan Dharma Praja, Volume 10, Nomor 1, 2017, https://doi.org/10.33701/jppdp.v10i1.379.

Laurensius Arliman S, Peran Komisi Perlindungan Anak Indonesia Untuk Mewujudkan Perlindungan Anak, Jurnal Respublica Volume 17, Nomor 2, 2018.

Laurensius Arliman S, Menjerat Pelaku Penyuruh Pengrusakan Barang Milik Orang Lain Dengan Mempertimbangkan Asas Fungsi Sosial, Jurnal Gagasan Hukum, Volume 1, Nomor 1, 2019.

Laurensius Arliman S, Ilmu Perundang-Undangan Yang Baik Untuk Negara Indonesia, Deepublish, Yogyakarta, 2019.

Laurensius Arliman S, Isdal Veri, Gustiwarni, Elfitrayenti, Ade Sakurawati, Yasri, Pengaruh Karakteristik Individu, Perlindungan Hak Perempuan Terhadap Kualitas Pelayanan Komnas Perempuan Dengan Kompetensi Sumber Daya Manusia Sebagai Variabel Mediasi, Jurnal Menara Ekonomi: Penelitian dan Kajian Ilmiah Bidang Ekonomi, Volume 6, Nomor 2, 2020.

Laurensius Arliman S, Pendidikan Kewarganegaraan, Deepublish, Yogyakarta, 2020.

Laurensius Arliman S, Makna Keuangan Negara Dalam Pasal Pasal 23 E Undang-Undang Dasar 1945, Jurnal Lex Librum, Volume 6, Nomor 2 Juni 2020, http://dx.doi.org/10.46839/1ljih.v6i2.151.

Laurensius Arliman S, Kedudukan Lembaga Negara Independen Di Indonesia Untuk Mencapai Tujuan Negara Hukum, Kertha Semaya Journal Ilmu Hukum, Volume 8, Nomor 7, 2020. 
Laurensius Arliman S, Pelaksanaan Assesment Oleh Polres Kepulauan Mentawai Sebagai Bentuk Pelaksanaan Rehabilitasi Bagi Pecandu Dan Korban Penyalahgunaan Narkotika, Jurnal Muhakkamah, Volume 5, Nomor 1, 2020.

Laurensius Arliman S, Aswandi Aswandi, Firgi Nurdiansyah, Laxmy Defilah, Nova Sari Yudistia, Ni Putu Eka, Viona Putri, Zakia Zakia, Ernita Arief, Prinsip, Mekanisme Dan Bentuk Pelayanan Informasi Kepada Publik Oleh Direktorat Jenderal Pajak, Volume 17, No Nomor, 2020.

Larensius Arliman S, Koordinasi PT. Pegadaian (Persero) Dengan Direktorat Reserse Narkoba Polda Sumbar Dalam Penimbangan Barang Bukti Penyalahgunaan Narkotika, UIR Law Review, Volume 4, Nomor 2, 2020, https://doi.org/10.25299/uirlrev.2020.vol4(1).3779.

Laurensius Arliman S, Tantangan Pendidikan Kewarganegaraan Pada Revolusi 4.0, Ensiklopedia Sosial Review, Volume 2, Nomor 3, 2020.

Muhammad Afif dan Laurensius Arliman S, Protection Of Children's Rights Of The Islamic And Constitutional Law Perspective Of The Republic Of Indonesia, Proceeding: Internasional Conference On Humanity, Law And Sharia (Ichlash), Volume 1, Nomor 2, 2020.

Otong Rosadi danLaurensius Arliman S, Urgensi Pengaturan Badan Pembinaan Idelogi Pancasila Berdasarkan Undang-Undang Sebagai State Auxiliary Bodies yang Merawat Pancasila dalam Perspektif Hak Asasi Manusia, Prosiding Konferensi Nasional Hak Asasi Manusia, Kebudayaan dan Tujuan Pembangunan Berkelanjutan Indonesia pada Masa Pandemi Covid-19: Tantangan untuk Keilmuan Hukum dan Sosial Volume 1, Universitas Pancasila, Jakarta, 2020. 